\title{
Pre-Harvest Modelling and Mitigation of Aflatoxins in Maize in a Changing Climatic Environment-A Review
}

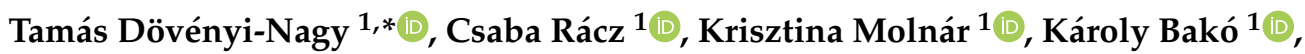 \\ Zsombor Szláma ${ }^{1} \mathbb{D}$, Ákos Jóźwiak ${ }^{2}$, Zsuzsa Farkas ${ }^{2}$, István Pócsi ${ }^{3}$ and Attila Csaba Dobos ${ }^{1}$ \\ 1 Agrometeorological and Agroecological Monitoring Centre, AKIT-DTTI, University of Debrecen, \\ H4032 Debrecen, Hungary; raczcs@agr.unideb.hu (C.R.); molnark@agr.unideb.hu (K.M.); \\ bakok@agr.unideb.hu (K.B.); szlama@agr.unideb.hu (Z.S.); dobosa@agr.unideb.hu (A.C.D.) \\ 2 Digital Food Institute, University of Veterinary Medicine Budapest, H1078 Budapest, Hungary; \\ jozwiak.akos@univet.hu (Á.J.); farkas.zsuzsa@univet.hu (Z.F.) \\ 3 Department of Molecular Biotechnology and Microbiology, Institute of Biotechnology, \\ Faculty of Science and Technology, University of Debrecen, H4032 Debrecen, Hungary; \\ pocsi.istvan@science.unideb.hu \\ * Correspondence: dovenyi@agr.unideb.hu
}

Received: 2 November 2020; Accepted: 2 December 2020; Published: 4 December 2020

\begin{abstract}
Aflatoxins (AFs) are harmful secondary metabolites produced by various moulds, among which Aspergillus flavus is the major AF-producer fungus. These mycotoxins have carcinogenic or acute toxigenic effects on both humans and food producing animals and, therefore, the health risks and also the potential economic damages mounted by them have led to legal restrictions, and several countries have set maximum allowable limits for AF contaminations in food and feed. While colonization of food and feed and AF production by A. flavus are highly supported by the climatic conditions in tropical and subtropical geographic regions, countries in the temperate climate zones are also increasingly exposed to AF-derived health risks due to climate change. In the present study, we have reviewed the available mathematical models as risk assessment tools to predict the possibility of $A$. flavus infection and levels of AF contaminations in maize in a changing climatic environment. After highlighting the benefits and possible future improvements of these models, we summarize the current agricultural practices used to prevent or, at least, mitigate the deleterious consequences of AF contaminations
\end{abstract}

Keywords: aflatoxin contamination; maize; climate change; field modelling; agro-technical measures; temperate climatic zone

Key Contribution: A review of mathematical models to predict AF contamination in maize, the possible methods of prevention and pre-harvest mitigation in a changing climatic environment.

\section{Introduction}

Aflatoxins (AFs) are dangerous secondary metabolites produced by various Aspergillus species, spoiling various crops, representing serious health threats to both humans and domestic animals and causing considerable economic losses worldwide. AFs are produced predominantly by A. flavus, A. parasiticus, A. nominus and some other moulds as well, with A. flavus being the main AF producer [1]. This fungus may infect crops including e.g., peanut, cottonseed, maize and various other nuts, cereals, spices, and dried fruits. While A. flavus has both toxigenic and non-toxigenic strains, under specific environmental conditions it may produce different AFs, with aflatoxin B1 (AFB1) being the most potent 
natural carcinogen known [2]. Apart from being highly carcinogenic, AFs can also be acutely toxic or even fatal for both livestock and humans if ingested in sufficient amounts.

Contaminations are more frequent and more severe in tropical and subtropical areas where temperature and humidity levels support growth of and infection by the fungus, as well as its AF production. However, under favourable climatic conditions in temperate climatic zones, especially during hot, dry periods, crops grown in those areas are also increasingly exposed to the risk of AF contamination.

Public health considerations have led to legal restrictions and several countries have regulations in place to define maximum permitted AF and AFB1 levels in food and feed. (For example, maximum 0.1-12 $\mu \mathrm{g} \mathrm{kg}^{-1}$ AFB1 in the EU, $20 \mathrm{ppb}$ total AF in the USA or 5-20 $\mu \mathrm{g} \mathrm{kg}^{-1}$ AFB1 in China [3-5].) Exceeding these acceptable limits may result in economic losses due to limited trade and economic opportunities: e.g., AFs are a major reason for rejecting imports of various products in the EU [6]. This has driven the development of various preventive measures, predicting tools and mitigation technologies (see Section 3). Preferred prevention methods include good agricultural practices (see Section 4), proper storage conditions and manufacturing protocols.

In order to assist policy makers and growers, several risk assessment tools have been developed for various crops. There are risk maps based on historical data, as well as empirical and mechanistic models available to predict AF levels and risk of exceeding regulatory thresholds. The peanut was the model developers' first main focus of interest because it is a main staple in African countries where some of the most severe cases occurred. However, in many European countries, maize (Zea mays L.) is a much more important crop and A. flavus and AF models for maize as a crop of interest are also available.

Development of mechanistic models requires good understanding of the pathogen's life cycle. A. flavus can colonize various plant species and affect seeds above and below ground level, resulting in diverse host-parasite interactions. The fungus generally survives in the soil or on plant residues. The major inoculum source to start the infection cycle is overwintering sclerotia. Flowering is the stage when maize as the host plant becomes susceptible to A. flavus colonization and infection occurs by air-borne conidia through the silk [7]. Colonization of maize kernels may continue throughout the growing season and is supported by insect damage [8]. Drought stress for the host plant under high temperatures and low humidity conditions, are associated with high aflatoxin contamination. A. flavus, in such an environment, may become the dominant pathogen in maize $[1,9,10]$.

The objective of the present study was to review the scientific literature regarding (a) the relation of climate change and A. flavus growth, infection and AF contamination in the Pannonian and the corresponding North-Mediterranean agro-ecological zone, (b) the possible solutions for predicting the level of AF contamination in maize in a changing climatic environment. The study especially focused on mathematical models. Finally, we summarize (c) the agricultural practices available to prevent and mitigate pre-harvest AF contamination when the models indicate an elevated risk.

\section{Environmental and Ecological Background}

\subsection{Pathogen Occurrence}

It is clearly seen that the incidence of aflatoxin-related health crises varies from year to year and is largely dependent on climatic factors [10-13]. Countries in the temperate climatic zone that today appear to be safe may therefore, as well, become more vulnerable to risk of disease and/or loss in crop production due to contamination, as climatic conditions change [14,15].

In the past, serious aflatoxin contamination was detected particularly in the developing countries of the tropical climatic zone. Benkerroum [11] reported past major outbreaks of aflatoxicosis associated with maize-based foods mainly, which occurred in West-India (1974), Kenya, 1981 and 2004, and Tanzania $(2016,2017)[12,13]$. Nevertheless, the presence of the pathogen is not limited to the tropical region. 
A. flavus has been proved to be present in most soils in Northern Italy since 2003 [16] (even in fields without AF issues in recent years), and the authors devised the AFLA-maize model with this in mind [17]. In a study by Leggieri et al. [18], the incidence of AFs exceeded $75 \%$ across all samples in Northern Italy over the years 2009-2011.

Since 1994, presence of the pathogen is unquestionable in Croatia, first detected from flour samples [19]. By 2013, the percentage of contaminated maize samples has already exceeded $38.1 \%$, and in almost one third of the cases, mycotoxin levels proved to be higher than the maximum permitted level [20].

In Serbia, A. flavus and AFB1 were isolated from $18.7 \%$ and $18.3 \%$ of the samples, respectively, [21]. Investigation of the influence of hotter and drier weather conditions on levels of aflatoxin in maize in 2015 found as high as one third of the samples unsuitable for human consumption due to overall AF concentration higher than $10.0 \mu \mathrm{g} \mathrm{kg}^{-1}$ [22].

Data published in the most recent decade [23-28] confirmed the presence of toxigenic strains of A. flavus and aflatoxin contamination in agricultural products and soil samples in Hungary and other neighbouring countries of the Pannonian agro-ecological zone.

\subsection{The Role of Ecophysiological Factors in Aflatoxin Contamination}

Germination, growth, infection and toxin production by Aspergillus species are determined by relatively few measurable parameters. In laboratory experiments, the variables taken into account are temperature, moisture content (water activity of the kernel: $a_{w}$, and/or relative humidity), $\mathrm{CO}_{2}$ concentration and $\mathrm{pH}$. It is important to note that in vitro experiments may substantially differ from field conditions where the host plant and pathogen culture are equally exposed to further, often more complex ecological factors.

\subsubsection{Laboratory (In Vitro) Findings}

According to Medina et al., the main driving force of AF production is a combination of three environmental factors, i.e., ambient temperature, water activity and elevated concentration of $\mathrm{CO}_{2}$ [29]. While three-way interactions between $\mathrm{CO}_{2}$ concentration, temperature and water activity do not have a significant effect on the growth of A. flavus, they do stimulate the biosynthesis of phenotypic AFB1 [30]. Detailed in vitro data have been published concerning the optimal range of temperature and $\mathrm{a}_{\mathrm{w}}$ for germination, growth and toxin production: A. flavus germinates under a wider range of temperature and water activity, while growth and toxin production have a narrower tolerance with an optimum of $35^{\circ} \mathrm{C} / 0.95 \mathrm{aw}$, and $33^{\circ} \mathrm{C} / 0.99 \mathrm{a}_{\mathrm{w}}$, respectively [31]. As a synopsis of further collections of data, Table 1 summarizes the range of ecological needs of growth and toxin production by A. flavus.

It is highly likely that ambient physiological stressors stimulate the mycotoxin production of various fungal species $[34,35]$. Two peaks can be identified in mycotoxin biosynthesis in relation to a combination of environmental parameters (temperature $\times \mathrm{a}_{\mathrm{w}}$ regimes). In a two-factorial experiment, microarray analysis showed that toxin production by Penicillium verrucosum, Fusarium culmorum and Aspergillus parasiticus reaches one major peak under the optimal growth conditions, and a second, lower one under mild stress conditions [34]. Findings were later confirmed by another study [36], suggesting a relative dominance of aflatoxin G1 production by A. parasiticus between $17-30{ }^{\circ} \mathrm{C}$ and marking water activity as a driving environmental parameter. In the case of AFB1, the key parameter was temperature. Ramirez et al. [37] and Giorni et al. [38] drew attention to the importance of different forms of water stress, of which matric stress is more likely to stimulate toxin producing fungi than solute stress. 
Table 1. Minimum, optimum and maximum values of temperature $\left({ }^{\circ} \mathrm{C}\right)$ and $\mathrm{a}_{\mathrm{w}}(-)$ for growth and toxin production by $A$. flavus grown in different in-vitro mediums.

\begin{tabular}{|c|c|c|c|c|c|c|c|}
\hline \multirow{2}{*}{ Substrate } & \multirow{2}{*}{ Parameter } & \multicolumn{3}{|c|}{ Growth } & \multicolumn{3}{|c|}{ Aflatoxin Production } \\
\hline & & $\min$ & opt & $\max$ & $\min$ & opt & $\max$ \\
\hline \multirow{2}{*}{ Whe at ${ }^{1}$} & Temperature & 15 & 35 & $>42.5$ & 15 & 25 & 42.5 \\
\hline & $\mathrm{a}_{\mathrm{w}}$ & 0.80 & 0.95 & $>0.95$ & 0.85 & 0.93 & 0.95 \\
\hline \multirow{2}{*}{ Sorghum $^{1}$} & Temperature & 15 & 37 & ns & 15 & 37 & ns \\
\hline & $\mathrm{a}_{\mathrm{w}}$ & $<0.91$ & 0.97 & ns & 0.94 & 0.97 & ns \\
\hline \multirow{2}{*}{ Rice $^{1}$} & Temperature & 20 & 33 & 42 & $<20$ & 35 & 37 \\
\hline & $\mathrm{a}_{\mathrm{W}}$ & 0.80 & 0.90 & 0.99 & 0.85 & 0.96 & 0.99 \\
\hline \multirow{2}{*}{ Malt extract-sucrose ${ }^{1}$} & Temperature & $12-15$ & 37 & 42 & 12 & 31 & 37 \\
\hline & $\mathrm{a}_{\mathrm{w}}$ & $0.8-0.85$ & $30-37$ & ns & 0.85 & 0.99 & 0.99 \\
\hline \multirow{2}{*}{ Maize-based medium ${ }^{2}$} & Temperature & 20 & 30 & ns & ns & 30 & ns \\
\hline & $\mathrm{a}_{\mathrm{w}}$ & 0.90 & 0.99 & ns & ns & 0.98 & $\mathrm{~ns}$ \\
\hline \multirow{2}{*}{ Other in vitro medium ${ }^{3}$} & Temperature & ns & 35 & ns & ns & 33 & ns \\
\hline & $\mathrm{a}_{\mathrm{w}}$ & ns & 0.95 & ns & ns & 0.99 & ns \\
\hline
\end{tabular}

${ }^{1}$ Adapted from [11], ${ }^{2}[32],{ }^{3}[33], \mathrm{ns}=$ not specified.

\subsubsection{Effect of Climatic Conditions in Field Environment}

Field studies agree on the predominant role of drought and high temperatures in elevated aflatoxin production in maize $[18,20,22]$. Despite their importance in providing valuable information on how theories work out in the complexity of ecophysiological factors and agronomic practice, these studies are still limited in number [39-41] compared to in vitro experiments (for further references see Section 4).

An analysis of 3000 maize samples harvested in Serbia during 2012-2016 [14] revealed that elevated AF concentration was pre-eminently a consequence of climatic extremes, such as serious drought and hot summer temperature. As an indirect effect, growth of maize plants suffers a setback due to heat and drought stress. This facilitates the infection of maize plants by any pathogenic fungi while hot and dry atmospheric conditions proved to be utterly favourable for the growth of A. flavus [42-54]. Dispersal of A. flavus and the infection itself requires airborne spores in the ambience of maize ears [55]. Leaf and soil wetness have a negative influence on the magnitude of infection, as well as falling precipitation that washes conidia and spores out of the atmosphere [55,56]. Since dry plant and soil surface are mostly associated with high to hot air temperature the latter is generally reported as a root cause of serious outbreaks of infection $[45,46,57]$.

Some mycotoxigenic species may be able to better adapt to stress than others and, therefore, this feature fundamentally determines ecological dominance in any given environment. Climatic extremes, such as drought and hot temperature, may not have a negative effect on the growth and toxin production by xerophilic fungi $[58,59]$. It was also found that the diversity of Aspergillus strains is strongly linked to the amount of rainfall and, accordingly, soil wetness and soil temperature. Consequently, AF production may also alter periodically and significantly at a given location [60-64]. High AF contamination in maize is often associated with weather conditions, as the preceding period was extremely warm, dry, and was characterised by a very low average rainfall. All of the aforementioned favour mould formation and AFB1 presence in maize. In accordance with the findings of preceding studies worldwide, hot and dry weather patterns with drought episodes proved to be typically favourable for higher than average AFB1 contamination in maize production [20].

\subsection{Effects of Climate Change on Crop Production-Yields}

Impact of climate change on agricultural productivity is detailed in several resources $[65,66]$. Agricultural production of the tropical and subtropical maize producing countries is generally expected to decrease parallel to a $+3{ }^{\circ} \mathrm{C}$ global warming scenario, whereas it may result in a considerably higher production potential in the temperate climate zones [67]. Predictions suggest drier and hotter summers in Western and Atlantic Europe, as well as in the Mediterranean region, with at least the risk of decrease 
in crop production. In parts of Asia, South America and the US, climatic conditions may be more beneficial to crop yields, similarly to Northern and Central Europe [68]. Yield responses in different emission scenarios have been estimated by Iglesias et al. [69] for each agroclimatic zone of Europe by the end of the present century. An 11-33\% increase was projected for the Southern continental zone (Hungary, Moldova, Romania, Serbia, Slovakia, Ukraine), and a similarly positive change in the yield of wheat, maize, and soybean crops for the Boreal, Alpine and parts of the North-Central Atlantic zones.

Although findings highly correspond with later reports in terms of growing potentials, the critical role of increasing yield variability is as well worth attention. More complex environmental parameters, such as fluctuations of groundwater level, are rarely taken into account in large scale predictions despite their effect on yield potential having already been proved. In Hungary, maize yield variability was found to be 18-38\% dependent on ground water decrease between 1986 and 2010 [70]. Added to the effect of higher temperatures, it has already slowed down crop production during the past decades [71]. By means of statistical tests, Moore and Lobell [72] introduced a novel method to substantiate that temperature and precipitation trends related to climate change caused a decrease in barley and wheat yields from the late 1980s, and a slight increase in that of sugar beet and maize. The question raised by the altering climatic conditions is how much an uncertain increase in yield would be able to compensate losses due to toxin contamination in the years of outbreaks.

\subsection{Effects of Climate Change on Crop Production-A Risk Factor in Food Safety}

A review presented by Paterson and Lima [73] acknowledges the possibility of plant pathogen fungi, such as A. flavus, spreading towards currently colder than optimal locations within the temperate climate zone. Colder climates may reach optimal temperatures for A. flavus in most global warming scenarios, unlike very cold, Nordic countries. In already hot climates, more frequent drought may result in higher mycotoxin production. In continuation of their previous review, Paterson and Lima [74] confirm research priorities already stated by Magan et al. [75], highlighting the importance of monitoring the geographical spread of mycotoxigenic fungi and maintaining quality databases prior to model development and further analysis of the effect of environmental factors. In addition to the inevitable value of in vitro data, there is an urgent need for field experiments to provide reliable in vivo data sources, as well.

The estimated decrease in crop yield due to pathogens may reach $16 \%$, with possible further specific losses in quality on account of the elevated mycotoxin contamination as a result of extreme maximum temperatures and frequent droughts [76]. Based on local reports from 1960, Bebber et al. [77] depict a $2.7 \mathrm{~km}$ yearly shift towards the poles in the habitats of crop pests, including plant pathogen fungi. Losses in crop production may surge in larger regions extended to the higher latitudes, mainly due to rapid global warming. In a comprehensive study on global mycotoxin risks versus climatic and other environmental parameters, Wu et al. [78] hypothesize a possible increase in aflatoxin and fumonisin contamination levels in maize for the US, predicting a similar process for the European maize producing regions.

Regarding air pollution as a further concern accompanying present time atmospheric changes, elevated $\mathrm{CO}_{2}$ level and $\mathrm{SO}_{2}$ pollution very likely influence host plant-pathogen relations in virtue of acidity. Acid environments may also have an effect on the growth of phylloplane fungi, either caused by sulphur dioxide or carbon dioxide [79-81].

For European maize and wheat production, the increasing degree of aflatoxin contamination has been predicted to be promoted as a major issue in food safety. A prediction model conducted by Battilani et al. [82] draws attention to a possible significant increase in ARI (aflatoxin risk index) in both a +2 and $+5{ }^{\circ} \mathrm{C}$ climate change scenario for the next 100 years, especially for Eastern Europe, the Balkan Peninsula and the Mediterranean region. Chauhan et al. [83] addresses the interactions between environmental conditions and maize plants. For the quantification of climatic risk in different locations of Australia, agronomic practices that minimise the effects of drought and high temperature 
were also taken into account and found to reduce ARI. It is also recommended for the processing industry to keep the produce of higher and lower risk areas separate, either in field or regional scale. A number of food safety issues may arise in staple foods from mycotoxin contamination to pesticide residues. As a response, quality monitoring, strict policies and regulation in the food chain will be of critical importance in the near future, urging adaptation and the establishment of a "climate-smart food system" [84-87].

\section{Risk Assessment and Modelling}

\subsection{Role and Significance of Risk Assessment and Modelling}

The role of risk assessment and modelling is to identify the risk factors and levels associated with specific growing seasons on the spread of A. flavus and AF contamination. With the help of these tools, prevention and mitigation of economic losses, animal and human health issues are possible.

Surveying AF is relatively slow and expensive, and since AF levels are usually determined after harvest, the results are not available for implementing within the season for pre-harvest mitigation [88]. Nevertheless, risk assessment tools may help to identify high and low risk areas and growing seasons, the identification of which is essential to take preventive measures or to increase the number of samples analysed for AF concentration.

The types of risk assessment tools available range from risk maps based on simple historic statistical data to sophisticated mechanistic models simulating the life cycle of $A$. flavus. However, with climate change (e.g., air temperature levels and rainfall distribution changing), statistical risk assessment solutions based on historical data may no longer identify risks as expected. Similar to empirical models, which may need to be recalibrated. Mechanistic models, on the other hand, are able to incorporate these changes.

\subsection{Modelling}

Modelling of interactions between environment and host plant during the growing season can enable assessment and quantification of pre-harvest AF risk and its potential management [83]. While 'mycotoxin' is a hot topic, efforts to model the risk of contamination in crops are still limited. Battilani [89] found that only $10 \%$ of mycotoxin related articles mention the keyword 'model' and only $1 \%$ of them mention 'crop', indicating that most models simulate AF production in vitro, without a target crop. Additionally, since issues associated with AF are more common in tropical and subtropical regions and affect staple crops in those areas, model developers' main focus was understandably peanut and pistachios. These crops are regularly contaminated as opposed to crops commonly grown in areas with temperate climate. Thus, if one is looking for a specific fungus on a specific crop, the number of publications available is very limited. Battilani et al. [17] found only two different approaches regarding modelling of $A$. flavus on maize in the field.

There can be several reasons behind this: difficulties of model development, the low interest in modelling, the unclear view on their support and the limited trust in their benefit.

Nevertheless, modelling the interactions between A. flavus, e.g., maize as the host plant and the environment during the growing season could enable prediction of the risk of AF contamination until harvest. This information is crucial for optimizing crop management both before and after harvest, leading to a mitigation of economic losses and consumer exposure.

\subsubsection{Types of Models}

Mathematical models can be classified into categories based on e.g., their iteration frequency and inner working mechanism. Crop modelling, as well as the AF models introduced in this paper, mostly involve discrete modelling, which means that events occur and variables change at some discrete points of time. There are daily, weekly or decadal models, but more frequent iteration is also possible if the input variables (e.g., hourly weather parameters) are available. 
Empirical models are developed by statistically analysing data collected in field trials and are used to describe how the driving factors (e.g., air temperature, rain) and the response variables (e.g., AF levels) are linked. Such a model will characterize the specific area, climate and seasons involved in the model development and may need recalibration when used in a different environment.

Mechanistic models try to enumerate the cause-and-effect relationships of the environmental variables and different states of a system. This way, they can describe and explain biological processes [90].

Model development usually involves both these approaches: in practice, mechanistic models are usually validated against field data using the principles of empirical models [91].

\subsubsection{In Vitro vs. In Vivo Fungal Growth Modelling}

Modelling of fungi has followed that of bacteria with some lag due to difficulties in model construction [92]. Since bacteria reproduce by fission, with growth normally taking place only on surfaces or homogeneously through a liquid medium, modelling is relatively easy. However, fungal growth involves germination, hyphal extension and penetration of the physical three-dimensional matrix of parts of the host plant or medium [93], making the model building task more difficult.

Despite the difficulties, mathematical modelling has been used to predict the extent of fungal growth and invasion as being dependent on environmental conditions [94-103]. Unlike strictly empirical models which are limited to the conditions in which an experiment is performed, semi-mechanistic and mechanistic models can provide insight into the behaviour of a biological system in more natural and uncontrolled environments [95].

A complex mathematical model that integrates the effects of temperature, water activity, $\mathrm{pH}$ and colony size on mould growth and aflatoxin production under laboratory conditions was proposed [95]. Various other authors have developed probability, empirical and mechanistic/semi-mechanistic models for a variety of toxigenic and spoilage fungi $[92,96,97]$, as well as specifically for A. flavus and AF prediction [90,98-103]. These models are usually based on in vitro trials and interactions between the fungus and input variables like temperature, $\mathrm{pH}$ and water activity.

While some of the models are able to simulate aflatoxin contamination well under in vitro conditions, in most cases on artificial culture media, their application under field conditions and on living plant parts needs further evaluation. Magan et al. [75] underlines the importance of the validation of existing predictive models. Model tests should include the evaluation of recent changes in the main driving climatic parameters, namely temperature, $\mathrm{CO}_{2}$ concentration and $\mathrm{a}_{\mathrm{w}}$, and their interactions, as well.

Probst and Cotty [104] pointed out the lack of correlation between the results of in vitro and in vivo experiments, cautioned on their use for predicting contamination in maize grains, and suggested crops of direct concern as culture media (e.g., maize grain).

Battilani et al. [105] found a discrepancy in the optimal $a_{w}$ range of in vitro vs. in vivo AF production. While in vitro results on artificial media suggest that AF levels decrease when $\mathrm{a}_{\mathrm{w}}$ decreases, field data show an incrementing AF production at kernel humidity below 28\% [1].

An important task to potentially improve AF models is to resolve this discrepancy between in vitro and in vivo results. However, the very nature of field trials, where factors, such as, e.g., weather or pests cannot be controlled in such a way as done in vitro, render the acquisition of proper field data difficult.

\subsubsection{Aflatoxin Prediction in Different Crops}

One method of risk assessment is to apply geostatistical methods to develop a predictive tool for identifying problematic regions, with a longer-term view. A sensitivity analysis carried out by Kerry et al. [106] suggests that at least 20 years of data are desirable to generate reliable space-time summaries of AF risk. Although these tools based on historic data can be useful to identify areas 
with high risk of AF contamination, they are usually unfit to predict AF levels in a changing climatic environment.

Similarly, empirical models or simple empirical equations which use meteorological data like temperature (daily mean or min-max) and precipitation, are mostly only valid to the area and crop on which the research was conducted.

Mechanistic models, on the other hand, try to represent complex natural processes through the underlying relations of the parts of the system and their numeric representation. Thus, to develop a mechanistic A. flavus/AF model, the knowledge and enumeration of the life cycle of A. flavus and the factors of AF production are necessary.

Although this paper's main focus is maize, it is worth mentioning some models targeting other crops. Since A. flavus and AFs are more prevalent in areas with a tropical climate, a large number of model developments concentrate on peanuts. While peanut, as an important crop in the southern USA and as a main staple in Africa, might seem less important in other countries in temperate regions, investigating the experiences of at least some peanut models can be useful for models with maize in focus [107-114]. Furthermore, some peanut models are direct predecessors of maize models, as they were used as a starting point by maize model developers $[83,109,114]$.

\subsubsection{AF Models in Maize}

Multiple mechanistic models were developed to predict pre-harvest AF contamination in field grown maize, based on the climatic dependencies of the A. flavus to colonize maize and produce AFs (Table 2) [10,17,83,115-117].

Table 2. Mathematical models to predict aflatoxin contamination in maize.

\begin{tabular}{cccc}
\hline Year & Authors & Name & Characteristics \\
\hline 2003 & Dowd, P. F. [116] & Mycotoxin predictor & Not published thoroughly. \\
\hline 2008 & Chauhan et al. [83] & - & Semi-mechanistic daily model based on aridity index. \\
\hline 2008 & Battilani et al. [10] & - & Empirical, decadal, aridity-based model. \\
\hline 2013 & Battilani et al. [17] & AFLA-maize & Mechanistic model evaluated in Italy. \\
\hline 2015 & Chauhan et al. [115] & - & Semi-mechanistic, aridity-based model evaluated in Kenya. \\
\hline 2018 & Damianidis et al. [117] & - & Semi-mechanistic, weekly, aridity-based. \\
\hline
\end{tabular}

Model 1 (Chauhan et al., 2008): A simulative model, using principles previously used for peanuts, was developed to quantify climatic risks of AF contamination in maize as an extension of the APSIM modelling environment $[83,114]$. The original model used as a starting point to develop this model was the peanut model by Wright et al. [109]. The calculation of the model's output, an aflatoxin risk index (ARI), is based on daily climatic and soil data during the maize grain filling period: air temperature, radiation, rainfall, soil water and soil nitrogen to simulate maize growth and yield. The fact that the model does not utilize water activity as a driver for aflatoxin production (in contrast to in vitro models) is a major benefit for farmers since $a_{w}$ is not a commonly used parameter in agriculture and is hard to assess on a daily basis. The simulation identifies the coincidences of $<20 \%$ available soil water and air temperature between $\geq 22$ and $\leq 35{ }^{\circ} \mathrm{C}$ from the start of the grain filling stage, which are accumulated in the aflatoxin risk index. The risk computed by the model was found to be related to the level of aflatoxin contamination, but was evaluated only for a limited number of locations. The model assumes inoculum always being present in the soil and sporulation, dispersal and germination non-limiting, which is a reasonable assumption given that the temperature range favourable for the growth of maize also favours germination and growth of A. flavus [118]. However, this model completely ignores the life cycle of $A$. flavus and can be considered mechanistic only on the basis of the maize phenology part. Thanks to the modelling framework, differences, e.g., between hybrids, plant density, and sowing dates can be expressed, but not the severity of insect damage. 
Additionally, the temperature and soil water thresholds used were derived from in vitro studies with peanuts as a substrate. Therefore, verification of these values for maize may increase the accuracy of the model. This work has been done in a revision of this model [115].

Model 2 (Battilani et al., 2008): Battilani et al. [10] used an aridity index (AI) to estimate the probability of AF contamination of the harvested maize above the European legal limit. This empirical approach, requiring easily available data as input, could give a rough prediction. This predictive system computed an AI to summarise meteorological conditions which was used to estimate the probability of AFB1 contamination. The model's input variables were daily mean air temperature and rain, and these were aggregated in ten-day periods to calculate the AI. The temperature and rain data were organized as decadal climatograms and the AI was computed as the difference of area under rain curve and area under temperature curve. Values of AI lower than zero indicate aridity. A logistic regression, using the decadal $\mathrm{AI}$ as independent variable, gave warning on AF contamination with $64 \%$ correct predictions. This rough predicting tool uses easily available weather data, is easy to calculate, but as an empirical model may have limited value in other areas. Without a mechanistic approach on part of the host plant and/or A. flavus, this model does not incorporate, e.g., the differences in susceptibility of the development stages of maize and the life cycle of $A$. flavus. These concerns were later addressed in a mechanistic model by Battilani et al. [17].

Model 3: AFLA-maize (Battilani et al., 2013): The AFLA-maize model [17] generates an index to predict the probability of exceeding the legal limit of AFB1. This prediction is based on a mechanistic approach, incorporating various stages of the infection cycle of $A$. flavus. It uses easily accessible weather variables (air temperature, relative humidity and rain) as inputs and was validated on Italian field data. The authors considered the inoculum source as non-limiting. The main components of this modelling approach were sporulation, infection, fungal growth and aflatoxin production at different temperatures and water activity levels. By completely abandoning the aridity index approach in their previous model, the authors ignored interactions happening due to the mismatch of soil moisture and its demand. This interaction, leading to development of drought and drought stress, seems to be a key factor in pre-harvest AF contamination. This model uses several sets of cardinal temperatures for different stages of the life cycle of A. flavus, like simulating growth or toxin production. However, these values and functions are based on in vitro trials which often are not appropriate to describe processes on the field. Other than drought stress (soil data and soil water processes), this model does not incorporate differences in susceptibility of hybrids and insect damage.

Model 4 (Chauhan et al., 2015): In a revised model, evaluated on maize grown in Kenya, Chauhan et al. [115] calculated an aflatoxin risk index based on water supply to demand ratios computed during the grain filling stages of maize. This model was also developed as a part of APSIM modelling framework where APSIM simulates maize growth, phenology and soil water balance using daily temperature, radiation and rainfall. In addition to daily weather variables, such a soil water balance model usually needs several other factors for describing the soil (e.g., field capacity, wilting point) and characterizing a plant (e.g., maximum rooting depth and plant height, length or temperature thresholds of different phenological stages). The authors used new cardinal temperatures on maize as a host plant for $A$. flavus growth based on their own in vitro trials. Unlike the model of Battilani et al. [17], the in vitro studies behind this model found that the optimal temperatures and temperature ranges for growth and AF production are similar. Inoculum, sporulation and germination in this model were considered non-limiting, water activity in grains before physiological maturity always being 1 ( $>24 \%$ grain moisture content) [46]. Trenk and Hartman [119] reported $17.5 \%$ moisture content to be a limit below which aflatoxin production will not occur. Considering drought stress as a driving factor for aflatoxin production, but using a mechanistic approach on the side of both the host plant and A. flavus, this model seems to mix and synthesize some major benefits of earlier models.

Model 5 (Damianidis et al., 2018): Damianidis et al. [117] calculated weekly drought indices (ARID) and found it useful to predict the risk for pre-harvest AF contamination in maize. Key factors for elevated risk of infection and AF level were drought stress around silking and during kernel 
development. The authors found a critical window between days 65 and 85 following planting when heat stress may result in increased AF contamination. Additionally, soil type and hybrid susceptibility to AF contamination proved to be statistically significant factors. Minimum temperature had the strongest positive influence on AF level over the 2 weeks after mid-silk. Low rainfall during the 2 weeks prior mid-silk and from day 43 after mid-silk to physiological maturity resulted in high AF contamination. According to these results, basic models incorporating minimum ambient temperature and the amount of precipitation could explain from 50 to $76 \%$ of the observed AF variability.

\subsection{Opportunities and Limitations of Model Usage}

An accurate prediction or estimation of the risk levels of AF contamination is of particular importance from the point of view of both healthcare and the economy. An easy to use mathematical model with good predicting capability is useful for growers, professional and specialist organizations (public health, farm advisory systems), competent authorities, economic operators (agricultural integrator companies, insurance and credit institutions) alike.

As we have seen based on the models introduced earlier, model developers try to aid this risk assessment work with different techniques. However, these approaches may present different challenges which users and decision makers should keep in mind. In addition, they should understand that a model is neither a panacea nor a perfect tool. While models have many uses in crop management, research and policy, they have their limitations.

Empirical, descriptive models are usually easier to comprehend, adapt and use, e.g., because of the fewer inputs needed, but they have to be calibrated to each new site and they cannot cope with a changing environment. Mechanistic models, on the other hand, are better able to model the interaction between the crop of interest and the environment. However, they can be more complex, making them more difficult to set up and use. They also may require more input data which may result in more accurate prediction, but not necessarily. If the required input data is unavailable and needs to be estimated or generated with a sub-model, the outputs may be even less stable compared to another model with fewer but reliable input data. Therefore, there are some cautions and limitations to consider by users and especially by developers of models.

Some simple, empirical, descriptive models use variables specific to the site and year the field trials have been carried out. Thus, these models have little predictive ability for growing seasons with unusual weather in a changing climate or for other locations. The extent of required input data is crucial. Some models use only meteorological variables and do not include effects specific to the field or management practices such as soil parameters, crop rotation, variety, and insect damage. Some models require variables not commonly used in agronomy or not assessed on a daily basis (e.g., $\mathrm{a}_{\mathrm{w}}$ ), thus leading to estimations. Being aware of these limitations helps both the end user choosing the right model for the specific field of use and also the developer to construct a model which actually fits the reality regarding, e.g., the range of required input variables.

In addition to input data, another major barrier of widespread use may be the lack of comparability. Presently, model performance is hard to assess or compare because individual tools were usually validated on different, very limited sets of maize samples acquired from fields of a single geographical region. Another problem is that the depth of the publication of the models' working mechanism is often not enough to reconstruct and validate them on an independent dataset.

Thus, assessment and comparison of models on an independent dataset from multiple geographical regions is required to help potential users and developers inciting widespread use and supporting focused development. Such a reference database should contain data from various regions and from many seasons. Beyond linked weather data and AF concentration of the sample, site specific soil data, plant specific (hybrid, phenological indicators) and agronomic factors (e.g., previous crop, tillage, dates of sowing and harvest, severity of insect damage) should be included in this database. Filtered datasets based on metadata can provide the basis for targeted testing and assessment of aflatoxin models aiming specific regions. 
Additionally, online access to these models with integrated weather databases may increase the number of users, as it happened with irrigation models and services monitoring and predicting the occurrence of various pests.

For the success of aflatoxin models, however, improvement of the predicting capability seems to be a key factor. For this improvement, more field trials and continuous evaluation and validation based on field trial results is required.

\section{Agronomy-Preventive and Corrective Steps}

The presented models can indicate the likelihood of AF contamination, which makes them suitable for farmers to monitor their crops and make informed decisions about various corrective steps to be undertaken to minimize contamination. The corrective steps should generally aim at lowering stress to the plant caused by drought, excessive heat, inadequate plant nutrition, insect damage, weeds, excessive plant populations, and other plant diseases, which cause stress and facilitate fungal infestations [120-151].

Proper crop management and an early harvest may be efficient to reduce AF contamination in maize. During planting, the seeding rate can be varied between different risk zones, or more resistant corn hybrids can be planted in the high-risk areas. During crop growth, irrigation, pest and nutrient management strategies could be altered depending on the risk zones. Finally, at harvest, areas with different levels of risk can be harvested earlier or separately [88]. In years with higher AF risk indicated, an early harvest followed by rapid artificial drying [120] can be considered compared to leaving the crop in the field for dry down.

Three major trends to reduce pre-harvest $A$. flavus colonization and aflatoxin contamination can be identified in the literature: resistance breeding, biocontrol, and good agricultural practices (GAP). Genotype, biocontrol and most agricultural practices are used as prevention strategies, but there are some measures, which can be implemented later in the season when models indicate the risk of severe AF contamination.

\subsection{Resistance Breeding}

Resistance is important since A. flavus is a weak pathogen [121] and crops are frequently very resistant to infection and AF contamination unless environmental conditions favour fungal growth and crop susceptibility [122]. Corn is a good example of a crop containing heritable resistance to AF contamination $[123,124]$. Dynamics of water loss during maturity of maize ears appears to be determined by genotype, too. Breeding is, therefore, a possible strategy in controlling water activity of grain, which is a key parameter in modelling the colonisation and infection of $A$. flavus and other fungi [125].

As a fundamental step to precede successful resistance breeding of maize hybrids, Szabó et al. [126] urge the establishment of a screening methodology for ear infection severity and coverage. Production and identification of resistant hybrids and inbred lines is on the way because they can significantly reduce AF levels [127]. The SErAT program in the USA evaluated 295 hybrids and identified 13 of them with AF levels significantly lower than check averages [128]. Evaluations by Fountain et al. [129], Okoth et al. [130] in Kenya and South Africa, Brown et al. [124] with African maize lines in the USA, Guo et al. [131], Stagnati et al. [132] etc. resulted in several promising resistant lines and candidates for resistance breeding.

Since wounding by insects contributes to the severity of infections [122], some GMO hybrids with Bt traits may reduce AF levels. However, while hybrids with Bt traits had lower insect damage, in some years this may not be consistently correlated to AF levels [133] and Bt traits are not sufficient to reduce AFs [8]. 


\subsection{Biocontrol}

Biocontrol methods are one of the most widely researched innovations, especially the usage of atoxigenic A. flavus as a competitor for the aflatoxin producer one. Other methods include biopesticides/stimulants and other substances, such as essential oils extracted from herbs.

The application of atoxigenic isolates of A. flavus as biocontrol agents is a cost-effective and environmentally friendly way to reduce AF levels [134]. Carefully selected atoxigenic genotypes efficiently reduce AF contamination of crops when applied prior to flowering in the field. This method was pioneered in the US, but similar products with native strains (Aflasafe) have been developed for several African countries. Studies show that they reduce AF concentrations in treated crops by $>80 \%$ in both field and storage conditions [135]. An aflatoxigenic A. flavus strain inside the kernels was suppressed by up to $82 \%$ when co-inoculated with a non-aflatoxigenic biocontrol strain. This resulted in a 73\% suppression in AF levels [136]. An evaluation of atoxigenic strains in Italy resulted in an average AFB1 reduction of $92.3 \%$ with one strain [41].

Another trend in innovation is the elaboration of different application technologies. While higher or more consistent AF reduction may be possible via liquid delivery of biocontrol strains, the granular formulation of a non-toxigenic strain of A. flavus is also cost effective [137]. However, this method is not frequently adopted because of the challenge of applying a granular product through the canopy of maize in its reproductive stage. Weaver et al. [138] investigated a water-dispersible formulation of biocontrol strain in maize. When AF was present at very high levels, there was no treatment that could provide significant protection against AF contamination. The new formulation resulted in $\geq 49 \%$ reduction in all five treatments with a biocontrol strain.

Accinelly et al. [139] evaluated a leaf application method. The formulation was shown to be adherent, resulting in colonization of leaf surfaces with the biocontrol strain, and to reduce AF contamination of harvested kernels by up to $80 \%$ in Northern Italy and by up to $89 \%$ in the Mississippi Delta. The percentage of AF-producing isolates in the soil reservoir was not significantly changed by this application method.

There are promising biocontrol agents other than atoxigenic A. flavus strains. In South Africa, a Trichoderma harzianum strain was used to control A. flavus infection. In two field trials, AF levels of controls were 57 and $65 \%$ higher than those of the treated plants [140]. Treatment of crops with antagonistic strains of Pseudomonas, Bacillus and Trichoderma spp. resulted in lower infection levels [141]. Garcia et al. demonstrated that an extract of Equisetum arvense and a mixture of Equisetum arvense and Stevia rebaudiana is effective against growth of A. flavus and AF production [142]. More recently, Lagogianni and Tsitsigiannis evaluated six biopesticides/stimulants and found most of them effective in reducing conidia and/or AFB1 production in vitro, and two of them in situ [143]. Treatment with Enterobacter cloacae resulted in a reduced AF production by $96.9 \%$ [144].

Despite these promising results, biocontrol methods have their limitations. Interactions between different species and strains are in a state of flux and inhibitory effect varies under different environmental conditions. When water is freely available, atoxigenic and toxigenic strains may co-exist [145]. Additionally, proof of claimed efficacy for farms is difficult to obtain [146].

\subsection{Good Agricultural Practice (GAP)}

Good agricultural practice is the third researched group of measures and another approach to control A. flavus and AF contamination, especially by mitigating water stress, insect damage and generally lowering crop susceptibility. Organic agriculture systems appear to be similarly or less affected than conventional systems [147].

In agricultural practice, a possible tool to reduce Aspergillus infection is to apply chemical fungicides. Hayes et al. addressed the questions of tolerance to antifungal treatments and specifies the pathways of the antifungal effects of chemical fungicides [148].

It is noteworthy that manure facilitates growth of microorganisms that suppress soil infections [149]. Furthermore, a lower crop density may also attenuate fungal attacks on the crop. A plant density 
of 75,000 plants ha ${ }^{-1}$ (compared to 55,000 and 64,000 plants ha ${ }^{-1}$ ) increased fungal incidence [150], however, increasing the planting density from 44,480 to 74,130 plants ha ${ }^{-1}$ did not impact toxin accumulation in another study [151]. Attenuation via management of nutrition is complicated, but a higher proportion of maize plots had detectable AF contamination under low $\mathrm{N}$ supplementation in comparison to a higher $\mathrm{N}$ level in Kenya [152].

Planting date may also significantly affect the number of infected maize kernels. Delayed planting proved to reduce mycotoxin levels [151]. Maize test crosses showed doubly higher AF levels in the late-maturing group under low $\mathrm{N}$ treatment [152].

Milani [122] coupled delayed harvest and late irrigation during warm periods to increased AF levels. Nevertheless, any agricultural strategy that aims to reduce or eliminate drought stress may reduce AF contamination. However, prolonged irrigation caused increased kernel infection since ear rot incidence increased by $76.8 \%$, compared to the control [153].

Parimi et al. have demonstrated the efficacy of education and raising farmer awareness: on-farm demonstrations of GAP resulted in a reduction of infections by $13-58 \%$ and AF levels of $62-94 \%$ compared to farmers' practices [154].

\section{Conclusions}

The ongoing climate change may support higher yield levels and may also lead to a possible increase of AF contamination in maize production of the Pannonian agro-ecological zone. Nevertheless, literature addressing the predictable changes in this region and the feasible pre-harvest prevention measures is still limited.

Recognizing the health risks and economic impacts of AF contaminations, various models have been developed already to predict AF levels in different crops based on climatic data. In this paper, we introduced and compared several models with maize as a crop of interest.

To support assessment and comparison of models an independent dataset from multiple geographical regions is required. Such a reference database should contain data from various regions and from many seasons. Additionally, online access to these models and improvement of their predicting capability may increase the number of users. For this improvement, more field trials and continuous evaluation and validation is required.

While the introduced empirical, semi-mechanistic and mechanistic models may indicate the severity of $A$. flavus colonization and AF contamination later in the growing season, good agricultural practice seems to be a widely accepted general preventive measure against AF contamination, e.g., by reducing water stress and insect damage.

Author Contributions: Conceptualization, A.C.D., Á.J. and Z.F.; methodology, A.C.D. and I.P.; resources, K.M., K.B. and Z.S.; writing —original draft preparation, C.R. and T.D.-N.; writing-review and editing, Á.J. and Z.F.; supervision, I.P.; project administration and funding acquisition, A.C.D. All authors have read and agreed to the published version of the manuscript.

Funding: This publication is related to the research program supported by projects No. GINOP-2.2.1-15-2016-00021, GINOP-2.2.1-15-2017-00076 and 2018-1.2.1-NKP-2018-00002.

Conflicts of Interest: The funders had no role in the design of the study; in the collection, analyses, or interpretation of data; in the writing of the manuscript, or in the decision to publish the results.

\section{References}

1. Payne, G.A. Process of contamination by aflatoxin producing fungi and their impacts on crops. In Mycotoxins in Agriculture and Food Safety; Sinha, K.K., Bhatnagar, D., Eds.; Marcel Dekker Inc.: New York, NY, USA, 1998; pp. 279-306.

2. WHO. Evaluation of Certain Food Additives and Contaminants. Forty-Ninth Report of the Joint FAO/WHO Expert Committee on Food Additives; WHO Technical Report Series 884; WHO: Geneva, Switzerland, 1999; ISBN 92-4-120884-8. 
3. Commission Regulation (EC) No 1881/2006 of 19 December 2006 Setting Maximum Levels for Certain Contaminants in Foodstuffs. Available online: http://data.europa.eu/eli/reg/2006/1881/2014-07-01 (accessed on 24 November 2020).

4. US FDA. CPG Sec 555.400 Foods-Adulteration with Aflatoxin. Available online: https://www.fda.gov/ regulatory-information/search-fda-guidance-documents/cpg-sec-555400-foods-adulteration-aflatoxin (accessed on 24 November 2020).

5. Tumukunde, E.; Ma, G.; Li, D.; Yuan, J.; Qin, L.; Wang, S. Current research and prevention of aflatoxins in China. World Mycotoxin J. 2020, 13, 121-138. [CrossRef]

6. RASFF Annual Report 2019. Available online: https://op.europa.eu/s/osNx (accessed on 24 November 2020).

7. Payne, G.A.; Widstrom, N.W. Aflatoxin in maize. Crit. Rev. Plant Sci. 1992, 10, 423-440. [CrossRef]

8. Isakeit, T.; Murray, S.; Pekar, J. Influence of corn GMO traits for insect control on aflatoxin and fumonisin contamination in Texas. Phytopathology 2016, 106, 46. [CrossRef]

9. Abbas, H.K.; Zablotowicz, R.M.; Locke, M.A. Spatial variability of Aspergillus flavus soil populations under different crops and corn grain colonization and aflatoxins. Can. J. Bot. 2004, 82, 1768-1775. [CrossRef]

10. Battilani, P.; Barbano, C.; Piva, G. Aflatoxin B1 contamination in maize related to the aridity index in North Italy. World Mycotoxin J. 2008, 1, 449-456. [CrossRef]

11. Benkerroum, N. Aflatoxins: Producing-molds, structure, health issues and incidence in Southeast Asian and Sub-Saharan African countries. Int. J. Environ. Res. Publ. Health 2020, 17, 1215. [CrossRef]

12. Lewis, L.; Onsongo, M.; Njapau, H.; Schurz-Rogers, H.; Luber, G.; Kieszak, S.; Nyamongo, J.; Backer, L.; Dahiye, A.M.; Misore, A.; et al. Aflatoxin contamination of commercial maize products during an outbreak of acute aflatoxicosis in Eastern and Central Kenya. Environ. Health Perspect. 2005, 113, 1763-1767. [CrossRef]

13. Wagacha, J.M.; Muthomi, J.W. Mycotoxin problem in Africa: Current status, implications to food safety and health and possible management strategies. Int. J. Food Microbiol. 2008, 124, 1-12. [CrossRef]

14. Kos, J.; Janić Hajnal, E.; Šarić, B.; Jovanov, P.; Mandić, A.; Đuragić, O.; Kokić, B. Aflatoxins in maize harvested in the Republic of Serbia over the period 2012-2016. Food Addit. Contam. Part B 2018, 11, 246-255. [CrossRef]

15. Camardo Leggieri, M.; Lanubile, A.; Dall'Asta, C.; Pietri, A.; Battilani, P. The impact of seasonal weather variation on mycotoxins: Maize crop in 2014 in northern Italy as a case study. World Mycotoxin J. 2019, 13, 25-36. [CrossRef]

16. Giorni, P.; Magan, N.; Pietri, A.; Bertuzzi, T.; Battilani, P. Studies on Aspergillus section Flavi isolated in northern Italy from maize. Int. J. Food Microbiol. 2007, 113, 330-338. [CrossRef] [PubMed]

17. Battilani, P.; Leggieri, M.C.; Rossi, V.; Giorni, P. AFLA-maize, a mechanistic model for Aspergillus flavus infection and aflatoxin B1 contamination in maize. Comput. Electron. Agric. 2013, 94, 38-46. [CrossRef]

18. Camardo Leggieri, M.; Bertuzzi, T.; Pietri, A.; Battilani, P. Mycotoxin occurrence in maize produced in Northern Italy over the years 2009-2011: Focus on the role of crop related factors. Phytopathol. Mediterr. 2015, 54, 212-221.

19. Halt, M. Aspergillus flavus and aflatoxin B1 in flour production. Eur. J. Epidemiol. 1994, 10, 555-558. [CrossRef] [PubMed]

20. Pleadin, J.; Vulić, A.; Perši, N.; Škrivanko, M.; Capek, B.; Cvetnić, Ž. Aflatoxin B1 occurrence in maize sampled from Croatian farms and feed factories during 2013. Food Control 2014, 40, 286-291. [CrossRef]

21. Jakić-Dimić, D.; Nesic, K.; Petrović, M. Contamination of cereals with aflatoxins, metabolites of fungi Aspergillus flavus. Biotechnol. Anim. Husb. 2009, 25, 1203-1208.

22. Hajnal, E.J.; Kos, J.; Krulj, J.; Krstovic, S.; Jajic, I.; Pezo, L.; Saric, B.; Nedeljkovic, N. Aflatoxins contamination of maize in Serbia: The impact of weather conditions in 2015. Food Addit. Contam. Part A 2017, 34, 1999-2010. [CrossRef]

23. Dobolyi, C.; Sebők, F.; Varga, J.; Kocsubé, S.; Szigeti, G.; Baranyi, N.; Szécsi, A.; Tóth, B.; Varga, M.; Kriszt, B.; et al. Occurrence of aflatoxin producing Aspergillus flavus isolates in maize kernels in Hungary. Acta Aliment. 2013, 42, 451-459. [CrossRef]

24. Kocsubé, S.; Varga, J.; Szigeti, G.; Baranyi, N.; Suri, K.; Tóth, B.; Toldi, É.; Bartók, T.; Mesterházy, Á. Aspergillus species as mycotoxin producers in agricultural products in central Europe. Zb. Matice Srp. Za Prir. Nauk. 2013, 124, 13-25. [CrossRef]

25. Sebők, F.; Dobolyi, C.; Zágoni, D.; Risa, A.; Krifaton, C.; Hartman, M.; Cserháti, M.; Szoboszlay, S.; Kriszt, B. Aflatoxigenic Aspergillus flavus and Aspergillus parasiticus strains in Hungarian maize fields. Acta Microbiol. Immunol. Hung. 2016, 63, 491-502. [CrossRef] 
26. Baranyi, N.; Despot, D.J.; Palágyi, A.; Kiss, N.; Kocsubé, S.; Szekeres, A.; Kecskeméti, A.; Bencsik, O.; Vágvölgyi, C.; Klaric, M.S.; et al. Identification of Aspergillus species in Central Europe able to produce G-type aflatoxins. Acta Biol. Hung. 2015, 66, 339-347. [CrossRef] [PubMed]

27. Man, S.; Tofana, M.; Muste, S.; Paucean, A.; Birou, A. Natural occurrence of aflatoxins in wheat from central Transylvania. Bull. Univ. Agric. Sci. Vet. Med. Cluj-Napoca 2011, 68, 311-316. [CrossRef]

28. Kos, J.; Mastilovic, J.; Hajnal, E.J.; Saric, B. Natural occurrence of aflatoxins in maize harvested in Serbia during 2009-2012. Food Control 2013, 34, 31-34. [CrossRef]

29. Medina, A.; Rodriguez, A.; Magan, N. Effect of climate change on Aspergillus flavus and aflatoxin $\mathrm{B}_{1}$ production. Front. Microbiol. 2014, 5, 348. [CrossRef] [PubMed]

30. Medina, A.; Rodriguez, A.; Sultan, Y.; Magan, N. Climate change factors and Aspergillus flavus: Effects on gene expression, growth and aflatoxin production. World Mycotoxin J. 2014, 8, 171-179. [CrossRef]

31. Sanchís, V.; Magan, N. Environmental profiles for growth and mycotoxin production. In Mycotoxins in Food: Detection and Control; Magan, N., Olsen, M., Eds.; Woodhead Publishing Ltd.: Cambridge, UK, 2004; pp. 174-189.

32. Bernáldez, V.; Córdoba, J.J.; Magan, N.; Peromingo, B.; Rodríguez, A. The influence of ecophysiological factors on growth, aflR, gene expression and aflatoxin B1 production by a type strain of Aspergillus flavus. LWT-Food Sci. Technol. 2017, 83, 283-291. [CrossRef]

33. Magan, N.; Baxter, E.S. Relationship between environmental factors and tenuazonic acid production by Alternaria isolates from sorghum. In Occurrence and Significance of Mycotoxins; Scudamore, K.A., Ed.; Slough Central Science Laboratories: Slough, UK, 1993; pp. 309-313.

34. Schmidt-Heydt, M.; Magan, N.; Geisen, R. Stress induction of mycotoxin biosynthesis genes in relation to abiotic factors. FEMS Microbiol. Lett. 2008, 284, 142-149. [CrossRef]

35. Fountain, J.C.; Pandey, A.K.; Nayak, S.N.; Bajaj, P.; Wang, H.; Kumar, V.; Chitikineni, A.; Abbas, H.K.; Scully, B.T.; Kemerait, R.C.; et al. Transcriptional responses of toxigenic and atoxigenic isolates of Aspergillus flavus to oxidative stress in aflatoxin-conducive and non-conducive media. World Mycotoxin J. 2020, 13, 443-457. [CrossRef]

36. Schmidt-Heydt, M.; Rüfer, C.E.; Abdel-Hadi, A.; Magan, N.; Geisen, R. The production of aflatoxin B1 or G1 by Aspergillus parasiticus at various combinations of temperature and water activity is related to the ratio of aflS to aflR expression. Mycotoxin Res. 2010, 26, 241-246. [CrossRef]

37. Ramirez, M.L.; Chulze, S.N.; Magan, N. Impact of osmotic and matric water stress on germination, growth, mycelial water potentials and endogenous accumulation of sugars and sugar alcohols by Fusarium graminearum. Mycology 2004, 96, 470-478. [CrossRef]

38. Giorni, P.; Battilani, P.; Magan, N. Effect of solute and matric potential on in vitro growth and sporulation of strains from a new population of Aspergillus flavus isolated in Italy. Fungal Ecol. 2008, 1, 102-106. [CrossRef]

39. Atehnkeng, J.; Ojiambo, P.S.; Cotty, P.J.; Bandyopadhyay, R. Field efficacy of a mixture of atoxigenic Aspergillus flavus Link:Fr vegetative compatibility groups in preventing aflatoxin contamination in maize (Zea mays L.). Biol. Control 2014, 74, 62-70. [CrossRef]

40. Williams, J.J.; Henry, W.B.; Smith, J.S.; Buehring, N.W.; Boykin, D.L. Aflatoxin accumulation in corn influenced by cultural practices in the U.S. Mid-South. Crop Sci. 2020, 60, 1-10. [CrossRef]

41. Mauro, A.; Garcia-Cela, E.; Pietri, A.; Cotty, P.J.; Battilani, P. Biological control products for aflatoxin prevention in Italy: Commercial field evaluation of atoxigenic Aspergillus flavus active ingredients. Toxins 2018, 10, 30-44. [CrossRef]

42. Cotty, P.J.; Jaime-Garcia, R. Influences of climate on aflatoxin producing fungi and aflatoxin contamination. Int. J. Food Microbiol. 2007, 119, 109-115. [CrossRef]

43. Diener, U.; Cole, R.; Sanders, T.; Payne, G.; Lee, L.; Klich, M. Epidemiology of aflatoxin formation by Aspergillus flavus. Ann. Rev. Phytopathol. 1987, 25, 249-270. [CrossRef]

44. McMillian, W.; Wilson, D.; Widstrom, N. Aflatoxin contamination of pre-harvest corn in Georgia: A six-year study of insect damage and visible Aspergillus flavus. J. Environ. Qual. 1985, 14, 200-202. [CrossRef]

45. Payne, G.A.; Cassel, D.K.; Adkins, C.R. Reduction of aflatoxin contamination in maize by irrigation and tillage. Phytopathology 1986, 76, 679-684. [CrossRef]

46. Payne, G.A.; Hagler, W.M.; Adkins, C.R. Aflatoxin accumulation in inoculated ears of field grown maize. Plant Dis. 1988, 72, 422-424. [CrossRef] 
47. Payne, G.A.; Thompson, D.L.; Lillehoj, E.B.; Zuber, M.S.; Adkins, C.R. Effect of temperature on the pre-harvest infection of maize kernels by Aspergillus flavus. Phytopathology 1988, 78, 1376-1380. [CrossRef]

48. Herrera, M.; Anadón, R.; Iqbal, S.Z.; Bailly, J.D.; Ariño, A. Climate change and food safety. In Food Safety: Basic Concepts, Recent Issues, and Future Challenges; Springer: Berlin/Heidelberg, Germany, 2016; pp. 149-160. ISBN 978-331939253-0/978-331939251-6. [CrossRef]

49. Sétamou, M.; Cardwell, K.; Schulthess, F.; Hell, K. Aspergillus flavus infection and aflatoxin contamination of pre-harvest maize in Benin. Plant Dis. 1997, 81, 1323-1327. [CrossRef] [PubMed]

50. Thompson, D.L.; Payne, G.A.; Lillehoj, E.B.; Zuber, M.S. Early appearance of aflatoxin in developing corn kernels after inoculation with Aspergillus flavus. Plant Dis. 1983, 67, 1321-1322. [CrossRef]

51. Widstrom, N.W. Aflatoxin in developing maize: Interactions among involved biota and pertinent econiche factors. In Handbook of Applied Mycology; Bhatnagar, D., Lillehoj, E.B., Arora, D.K., Eds.; Marcel Dekker Inc.: New York, NY, USA, 1992; Volume 5, pp. 23-58. ISBN 978-0-8247-8551-2.

52. Widstrom, N.W. The aflatoxin problem with corn grain. In Advances in Agronomy; Sparks, D.L., Ed.; Academic Press: New York, NY, USA, 1996; Volume 56, pp. 219-280. ISBN 9780120007561.

53. Widstrom, N.W.; Guo, B.Z.; Wilson, D.M. Integration of crop management and genetics for control of pre-harvest aflatoxin contamination of corn. Toxin Rev. 2003, 22, 195-223. [CrossRef]

54. Widstrom, N.W.; McMillian, W.; Beaver, R.; Wilson, D.M. Weather associated changes in aflatoxin contamination of pre-harvest maize. J. Prod. Agric. 1990, 3, 196-199. [CrossRef]

55. Jones, R.; Duncan, H.; Payne, G.; Leonard, K. Factors influencing infection by Aspergillus flavus in silk-inoculated corn. Plant Dis. 1980, 64, 859-863. [CrossRef]

56. Jones, R.; Duncan, H.; Hamilton, P. Planting date, harvest date, and irrigation effects on infection and aflatoxin production by Aspergillus flavus in field corn. Phytopathology 1981, 71, 810-816. [CrossRef]

57. Shearer, J.; Sweets, L.; Baker, N.; Tiffany, L. A study of Aspergillus flavus/parasiticus in Iowa crop fields: 1988-1990. Plant Dis. 1992, 76, 19-22. [CrossRef]

58. Williams, J.P.; Hallsworth, J.E. Limits of life in hostile environments: No barriers to biosphere function? Environ. Microbiol. 2009, 11, 3292-3308. [CrossRef]

59. Chin, J.P.; Megaw, J.; Magill, C.L.; Nowotarski, K.; Williams, J.P.; Bhaganna, P.; Linton, M.; Patterson, M.F.; Underwood, G.J.C.; Mswaka, A.Y.; et al. Solutes determine the temperature windows for microbial survival and growth. Proc. Natl. Acad. Sci. USA 2010, 107, 7835-7840. [CrossRef]

60. Bayman, P.; Cotty, P. Vegetative compatibility and genetic diversity in the Aspergillus flavus population of a single field. Can. J. Bot. 1991, 69, 1707-1711. [CrossRef]

61. Horn, B.W.; Dorner, J.W. Regional differences in production of aflatoxin B1 and cyclopiazonic acid by soil isolates of Aspergillus flavus along a transect within the United States. Appl. Environ. Microbiol. 1999, 65, 1444-1449. [CrossRef] [PubMed]

62. Horn, B.W.; Dorner, J.W. Effect of competition and adverse culture conditions on aflatoxin production by Aspergillus flavus through successive generation. Mycologia 2002, 94, 741-751. [CrossRef] [PubMed]

63. Orum, T.V.; Bigelow, D.M.; Cotty, P.J.; Nelson, M.R. Using predictions based on geostatistics to monitor trends in Aspergillus flavus strain composition. Phytopathology 1999, 89, 761-769. [CrossRef]

64. Jaime-Garcia, R.; Cotty, P.J. Crop rotation and soil temperature influence the community structure of Aspergillus flavus in soil. Soil Biol. Biochem. 2010, 42, 1842-1847. [CrossRef]

65. European Commission. Adapting to Climate Change in Europe-Options for EU Action. Green Paper from the Commission to the Council, the European Parliament, the European Economic and Social Committee and the Committee of the Regions. \{SEC(2007) 849\} COM(2007); European Commission: Brussels, Belgium, 2007; pp. 3-13.

66. Solomon, S.; Quin, D.; Manning, M.; Alley, R.B.; Berstein, T.; Bindoff, N.L.; Chen, Z.; Chidthaisong, A.; Gregory, J.M.; Hegerl, G.C.; et al. Technical summary. In Climate Change 2007: The Physical Science Basis. Contribution of Working Group 1 to the Fourth Assessment Report of the Intergovernmental Panel on Climate Change; Solomon, S., Quin, D., Manning, M., Chen, Z., Marquis, M., Averyt, K.B., Tignor, M., Miller, H.L., Eds.; Cambridge University Press: Cambridge, UK; New York, NY, USA, 2007; pp. 19-91.

67. Intergovernmental Panel on Climate Change (IPCC). Contribution of working groups I, II, and III to the fourth assessment report of the intergovernmental panel on climate change. In Climate Change 2007, Synthesis Report; Intergovernmental Panel on Climate Change: Geneva, Switzerland, 2007; pp. 50-52. Available online: https://www.ipcc.ch/report/ar4/syr/ (accessed on 24 November 2020). 
68. Tao, F.L.; Zhang, Z. Impacts of climate change as a function of global mean temperature: Maize productivity and water use in China. Clim. Chang. 2011, 105, 409-432. [CrossRef]

69. Iglesias, A.; Garrote, L.; Quiroga, S.; Moneo, M. A regional comparison of the effects of climate change on agricultural crops in Europe. Clim. Chang. 2012, 112, 29-46. [CrossRef]

70. Pinke, Z.; Decsi, B.; Kozma, Z.; Vári, Á.; Lövei, G.L. A spatially explicit analysis of wheat and maize yield sensitivity to changing groundwater levels in Hungary, 1961-2010. Sci. Total Environ. 2020, 715, 136555. [CrossRef]

71. Pinke, Z.; Lövei, G.L. Increasing temperature cuts back crop yields in Hungary over the last 90 years. Glob. Chang. Biol. 2017, 23, 5426-5435. [CrossRef]

72. Moore, F.C.; Lobell, D.B. The fingerprint of climate trends on European crop yields. Proc. Natl. Acad. Sci. USA 2015, 112, 2670-2675. [CrossRef]

73. Paterson, R.; Lima, N. How will climate change affect mycotoxins in food? Food Res. Int. 2010, 43, $1902-1914$. [CrossRef]

74. Paterson, R.; Lima, N. Further mycotoxin effects from climate change. Food Res. Int. 2011, 44, $2555-2566$. [CrossRef]

75. Magan, N.; Medina, A.; Aldred, D. Possible climate change effects on mycotoxin contamination of food crops pre- and post-harvest. Plant Pathol. 2011, 60, 150-163. [CrossRef]

76. Porter, J.R.; Xie, L.; Challinor, A.J.; Cochrane, K.; Howden, S.M.; Iqbal, M.M.; Lobell, D.B.; Travasso, M.I. Food security and food production systems. In Climate Change 2014: Impacts, Adaptation, and Vulnerability. Part A: Global and Sectoral Aspects. Contribution of Working Group II to the Fifth Assessment Report of the Intergovernmental Panel on Climate Change; Field, C.B., Barros, V.R., Dokken, D.J., Mach, K.J., Mastrandrea, M.D., Bilir, T.E., Chatterjee, M., Ebi, K.L., Estrada, Y.O., Genova, R.C., et al., Eds.; Cambridge University Press: Cambridge, UK; New York, NY, USA, 2014; pp. 485-533.

77. Bebber, D.P.; Ramotowski, M.A.T.; Gurr, S.J. Crop pests and pathogens move poleward in a warming world. Nat. Clim. Chang. 2013, 3, 985-988. [CrossRef]

78. Wu, F.; Bhatnagar, D.; Bui-Klimke, T.; Carbone, I.; Hellmich, R.; Munkvold, G.; Payne, G.; Takle, E. Climate change impacts on mycotoxin risks in US maize. World Mycotoxin J. 2011, 4, 79-93. [CrossRef]

79. McLeod, A.R. Effects of open-air fumigation with sulphur dioxide on the occurrence of fungal pathogens in winter cereals. Phytopathology 1988, 78, 88-94. [CrossRef]

80. Magan, N.; McLeod, A.R. Effect of open air fumigation with sulphur dioxide on the occurrence of phylloplane fungi on winter barley. Agric. Ecosyst. Environ. 1991, 33, 245-261. [CrossRef]

81. Mansfield, P.J.; Bell, J.N.B.; McLeod, A.R.; Wheeler, B.E.J. Effects of sulphur dioxide on the development of fungal diseases of winter barley in an open-air fumigation system. Agric. Ecosyst. Environ. 1991, 33, 215-232. [CrossRef]

82. Battilani, P.; Toscano, P.; Van der Fels-Klerx, H.J.; Moretti, A.; Camardo Leggieri, M.; Brera, C.; Rortais, A.; Goumperis, T.; Robinson, T. Aflatoxin B1 contamination in maize in Europe increases due to climate change. Sci. Rep. 2016, 6, 24328. [CrossRef]

83. Chauhan, Y.S.; Wright, G.C.; Rachaputi, N.C. Modelling climatic risks of aflatoxin contamination in maize. Aust. J. Exp. Agric. 2008, 48, 358-366. [CrossRef]

84. Kuiper-Goodman, T. Risk assessment and risk management of mycotoxins in food. In Mycotoxins in Food: Detection and Control; Magan, N., Olsen, M., Eds.; Woodhead Publishing: Cambridge, UK, 2004; Chapter 1; pp. 3-31.

85. Miraglia, M.; Marvin, H.J.P.; Kleter, G.A.; Battilani, P.; Brera, C.; Coni, E.; Cubadda, F.; Croci, L.; De Santis, B.; Dekkers, S.; et al. Climate change and food safety: An emerging issue with special focus on Europe. Food Chem. Toxicol. 2009, 47, 1009-1021. [CrossRef]

86. Lake, I.R.; Hooper, L.; Abdelhamid, A.; Bentham, G.; Boxall, A.B.A.; Draper, A. Climate change and food security: Health impacts in developed countries. Environ. Health Perspect. 2012, 120, 1520-1526. [CrossRef] [PubMed]

87. Wheeler, T.; von Braun, J. Climate change impacts on global food security. Science 2013, 341, 508-513. [CrossRef] [PubMed]

88. Yoo, E.; Kerry, R.; Ingram, B.; Ortiz, B.; Scully, B. Defining and characterizing aflatoxin contamination risk areas for corn in Georgia, USA: Adjusting for collinearity and spatial correlation. Spat. Stat. 2018, 28, 84-104. [CrossRef] 
89. Battilani, P. Recent advances in modeling the risk of mycotoxin contamination in crops. Curr. Opin. Food Sci. 2016, 11, 10-15. [CrossRef]

90. Garcia, D.; Ramos, A.J.; Sanchis, V.; Marín, S. Predicting mycotoxins in food: A review. Food Microbiol. 2009, 26, 757-769. [CrossRef]

91. Campbell, C.L.; Madden, M.V. Modeling and data analysis. In Introduction to Plant Disease Epidemiology; Wiley \& Sons: New York, NY, USA, 1990; pp. 129-160.

92. Gibson, A.M.; Baranyi, J.; Pitt, J.I.; Eyles, M.J.; Roberts, T.A. Predicting fungal growth: The effects of water activity on Aspergillus flavus and related species. Int. J. Food Microbiol. 1994, 23, 419-431. [CrossRef]

93. Gibson, A.M.; Hocking, A.D. Advances in the predictive modelling of fungal growth in food. Trends Food Sci. Technol. 1997, 8, 353-358. [CrossRef]

94. Samapundo, S.; Devlieghere, F.; Meulenaer, B.; Geeraerd, A.H.; Van Impe, J.F.; Debevre, J.M. Predictive modelling of the individual and combined effect of water activity and temperature on the radial growth of Fusarium verticilliodes and F. proliferatum on corn. Int. J. Food Microbiol. 2005, 105, 35-52. [CrossRef]

95. Pitt, R.E. A descriptive model of mold growth and aflatoxin formation as affected by environmental conditions. J. Food Prot. 1993, 56, 139-146. [CrossRef]

96. Cuppers, H.G.A.M.; Oomes, S.; Brul, S. A model for the combined effects of temperature and salt concentration on growth rate of food spoilage moulds. Appl. Environ. Microbiol. 1997, 63, 3764-3769. [CrossRef]

97. Sautour, M.; Soares Mansur, C.; Divies, C.; Bensoussan, M.; Dantigny, P. Comparison of the effects of temperature and water activity on growth rate of food spoilage moulds. J. Ind. Microbiol. Biotechnol. 2002, 28, 311-316. [CrossRef] [PubMed]

98. Gqaleni, N.; Smith, J.E.; Lacey, J.; Gettinby, G. Effects of temperature, water activity, and incubation time on production of aflatoxins and cyclopiazonic acid by an isolate of Aspergillus flavus in surface agar culture. Appl. Environ. Microbiol. 1997, 63, 1048-1053. [CrossRef] [PubMed]

99. Molina, M.; Giannuzzi, L. Modelling of aflatoxin production by Aspergillus parasiticus in a solid medium at different temperatures, $\mathrm{pH}$ and propionic acid concentrations. Food Res. Int. 2002, 35, 585-594. [CrossRef]

100. Abdel-Hadi, A.; Schmidt-Heydt, M.; Parra, R.; Geisen, R.; Magan, N. A systems approach to model the relationship between aflatoxin gene cluster expression, environmental factors, growth and toxin production by Aspergillus flavus. J. R. Soc. Interface 2012, 9, 757-767. [CrossRef]

101. Mousa, W.; Ghazali, F.M.; Jinap, S.; Ghazali, H.M.; Radu, S. Modelling the effect of water activity and temperature on growth rate and aflatoxin production by two isolates of Aspergillus flavus on paddy. J. Appl. Microbiol. 2011, 111, 1262-1274. [CrossRef]

102. Astoreca, A.; Vaamonde, G.; Dalcero, A.; Ramos, A.J.; Marín, S. Modelling the effect of temperature and water activity of Aspergillus flavus isolates from corn. Int. J. Food Microbiol. 2012, 156, 60-67. [CrossRef]

103. Garcia, D.; Ramos, A.J.; Sanchis, V.; Marín, S. Modeling kinetics of aflatoxin production by Aspergillus flavus in maize-based medium and maize grain. Int. J. Food Microbiol. 2013, 162, 182-189. [CrossRef]

104. Probst, C.; Cotty, P.J. Relationship between in vivo and in vitro aflatoxin production: Reliable prediction of fungal ability to contaminate maize with aflatoxins. Fungal Biol. 2012, 116, 503-510. [CrossRef]

105. Battilani, P.; Formenti, S.; Ramponi, C.; Rossi, V. Dynamic of water activity in maize hybrids is crucial for fumonisin contamination in kernels. J. Cereal Sci. 2011, 54, 467-472. [CrossRef]

106. Kerry, R.; Ortiz, B.V.; Ingram, B.R.; Scully, B.T. A spatio-temporal investigation of risk factors for aflatoxin contamination of corn in southern Georgia, USA using geostatistical methods. Crop Prot. 2017, 94, 144-158. [CrossRef]

107. Thai, C.N.; Blankenship, P.D.; Cole, R.J.; Sanders, T.H.; Domer, J.W. Relationship between aflatoxin production and soil temperature for peanuts under drought stress. Trans. ASABE 1990, 33, 324-329. [CrossRef]

108. Parmar, R.S.; McClendon, R.W.; Hoogenboom, G.; Blankenship, P.D.; Cole, R.J.; Dorner, J.W. Estimation of aflatoxin contamination in pre-harvest peanuts using neural networks. Trans. ASABE 1997, 40, 809-813.

109. Wright, G.C.; Rachaputi, N.C.; Krosch, S.; Broome, A. Reducing aflatoxin in the Australian peanut crop using integrated harvesting management system. In Proceedings of the American Peanut Research and Education Society Conference, Clear Water Beach, Tampa, FL, USA, 8-11 July 2003; p. 66.

110. Wright, G.C.; Hansen, R.B. Climatic effects on aflatoxin incidence and management in peanuts. In Proceedings of the 2nd Australian Peanut Conference, Gold Coast, Australia, 13-16 July 1997; pp. 62-65. 
111. Wright, G.C.; Rachaputi, N.C.; Chauhan, Y.S.; Robson, A. Increasing productivity and quality of peanuts using novel crop modeling and remote sensing technologies. Prospects and emerging opportunities for peanut quality and utilisation technology. In Proceedings of the International Peanut Conference, Kasetsart University, Bangkok, Thailand, 9-12 January 2005; pp. 14-17.

112. Rachaputi, N.C.; Wright, G.; Krosch, S.; Tatnell, J. On-farm monitoring and management of aflatoxin contamination in Australian peanuts. In Proceedings of the 4th International Crop Science Congress, Brisbane, Australia, 21 September-1 October 2004.

113. Chauhan, Y.S.; Wright, G.C.; Holzworth, D.; Rachaputi, R.C.N.; Payero, J.O. AQUAMAN: A web-based decision support system for irrigation scheduling in peanuts. Irrig. Sci. 2013, 31, 271-283. [CrossRef]

114. Chauhan, Y.S.; Wright, G.C.; Rachaputi, R.C.N.; Holzworth, D.; Broome, A.; Krosch, S. Application of a model to assess aflatoxin risk in peanuts. J. Agric. Sci. 2010, 148, 341-351. [CrossRef]

115. Chauhan, Y.; Tatnell, J.; Krosch, S.; Karanja, J.; Gnonlonfin, B.; Wanjuki, I.; Wainaina, J.; Harvey, J. An improved simulation model to predict pre-harvest aflatoxin risk in maize. Field Crops Res. 2015, 178, 91-99. [CrossRef]

116. Dowd, P.F. Validation of a mycotoxin predicting computer program for U.S. midwest grown maize in commercial fields. Proceedings of the aflatoxin and fungal genomics workshop. Mycopathologia 2003, $157,463$.

117. Damianidis, D.; Ortiz, B.V.; Windham, G.L.; Bowen, K.L.; Hoogenboom, G.; Scully, B.T.; Hagan, A.; Knappenberger, T.; Woli, P.; Williams, W.P. Evaluating a generic drought index as a predictive tool for aflatoxin contamination of corn: From plot to regional level. Crop Prot. 2018, 113, 64-74. [CrossRef]

118. Marín, S.; Sanchis, V.; Sáenz, R.; Ramos, A.J.; Vinas, I.; Magan, N. Ecological determinants for germination and growth of some Aspergillus and Penicillium spp. from maize grain. J. Appl. Microbiol. 1998, 84, 25-36. [CrossRef] [PubMed]

119. Trenk, H.L.; Hartman, P.A. Effects of moisture content and temperature on aflatoxin production in corn. Appl. Microbiol. 1970, 19, 781-784. [CrossRef] [PubMed]

120. Hell, K.; Mutegi, C. Aflatoxin control and prevention strategies in key crops of Sub-Saharan Africa. Afr. J. Microbiol. Res. 2011, 5, 459-466.

121. Windham, G.L.; Williams, W.P. Effect of inoculum concentrations of Aspergillus flavus and A-parasiticus on aflatoxin accumulation and kernel infection in resistant and susceptible maize hybrids. Phytoparasitica 2016, 44, 333-339. [CrossRef]

122. Milani, J.M. Ecological conditions affecting mycotoxin production in cereals: A review. Vet. Med. 2013, 58, 405-411. [CrossRef]

123. Mesterházy, Á. Control of mycotoxin contamination in cereals by breeding. In Mycotoxins in Food, Feed and Bioweapons; Rai, M., Varma, A., Eds.; Springer: Berlin, Germany, 2009; pp. 163-177. ISBN 978-3-642-00724-8. [CrossRef]

124. Brown, R.L.; Williams, W.P.; Windham, G.L.; Menkir, A.; Chen, Z.Y. Evaluation of African-bred maize germplasm lines for resistance to aflatoxin accumulation. Agronomy 2016, 6, 24. [CrossRef]

125. Brooking, I.B. Maize ear moisture during gain-filling, and its relation to physiological maturity and grain drying. Field Crops Res. 1990, 23, 55-68. [CrossRef]

126. Szabó, B.; Tóth, B.; Tóth Toldiné, E.; Varga, M.; Kovács, N.; Varga, J.; Kocsubé, S.; Palágyi, A.; Bagi, F.; Budakov, D.; et al. A new concept to secure food safety standards against Fusarium species and Aspergillus flavus and their toxins in maize. Toxins 2018, 10, 372. [CrossRef]

127. Windham, G.L.; Williams, W.P.; Mylroie, J.E.; Reid, C.X.; Womack, E.D. A histological study of Aspergillus flavus colonization of wound inoculated maize kernels of resistant and susceptible maize hybrids in the field. Front. Microbiol. 2018, 9, 799. [CrossRef]

128. Wahl, N.; Murray, S.C.; Isakeit, T.; Krakowsky, M.; Windham, G.L.; Williams, W.P.; Guo, B.; Ni, X.; Knoll, J.; $\mathrm{Xu}, \mathrm{W}$; et al. Identification of resistance to aflatoxin accumulation and yield potential in maize hybrids in the Southeast Regional Aflatoxin Trials (SERAT). Crop Sci. 2017, 57, 202-215. [CrossRef]

129. Fountain, J.C.; Abbas, H.K.; Scully, B.T.; Li, H.; Lee, R.D.; Kemerait, R.C.; Guo, B. Evaluation of maize inbred lines and topcross progeny for resistance to pre-harvest aflatoxin contamination. Crop J. 2019, 7, 118-125. [CrossRef]

130. Okoth, S.; Rose, L.J.; Ouko, A.; Beukes, I.; Sila, H.; Mouton, M.; Flett, B.C.; Makumbi, D.; Viljoen, A. Field evaluation of resistance to aflatoxin accumulation in maize inbred lines in Kenya and South Africa. J. Crop Improv. 2017, 31, 862-878. [CrossRef] 
131. Guo, B.; Ji, X.; Ni, X.; Fountain, J.C.; Li, H.; Abbas, H.K.; Lee, R.D.; Scully, B.T. Evaluation of maize inbred lines for resistance to pre-harvest aflatoxin and fumonisin contamination in the field. Crop J. 2017, 5, 259-264. [CrossRef]

132. Stagnati, L.; Martino, M.; Battilani, P.; Busconi, M.; Lanubile, A.; Marocco, A. Development of early maturity maize hybrids for resistance to Fusarium and Aspergillus ear rots and their associated mycotoxins. World Mycotoxin J. 2020, 13, 459-471. [CrossRef]

133. Bowen, K.L.; Flanders, K.L.; Hagan, A.K.; Ortiz, B. Insect damage, aflatoxin content, and yield of Bt corn in Alabama. J. Econ. Entomol. 2014, 107, 1818-1827. [CrossRef] [PubMed]

134. Šimončicová, J.; Kaliňáková, B.; Kryštofová, S. Aflatoxins: Biosynthesis, prevention and eradication. Acta Chim. Slovaca 2017, 10, 123-131. [CrossRef]

135. Bandyopadhyay, R.; Ortega-Beltran, A.; Akande, A.; Mutegi, C.; Atehnkeng, J.; Kaptoge, L.; Senghor, A.L.; Adhikari, B.N.; Cotty, P.J. Biological control of aflatoxins in Africa: Current status and potential challenges in the face of climate change. World Mycotoxin J. 2016, 9, 771-789. [CrossRef]

136. Hruska, Z.; Rajasekaran, K.; Yao, H.; Kinkaid, R.; Darlington, D.; Brown, R.L.; Bhatnagar, D.; Cleveland, T.E. Co-inoculation of aflatoxigenic and non-aflatoxigenic strains of Aspergillus flavus to study fungal invasion, colonization, and competition in maize kernels. Front. Microbiol. 2014, 5, 122. [CrossRef]

137. Accinelli, C.; Mencarelli, M.; Balogh, A.; Ulmer, B.J.; Screpanti, C. Evaluation of field application of fungi-inoculated bioplastic granules for reducing herbicide carry over risk. Crop Prot. 2015, 67, 243-250. [CrossRef]

138. Weaver, M.A.; Abbas, H.K.; Jin, X.; Elliott, B. Efficacy of water-dispersible formulations of biological control strains of Aspergillus flavus for aflatoxin management in corn. Food Addit. Contam. 2016, 33, 346-351. [CrossRef]

139. Accinelli, C.; Abbas, H.K.; Vicari, A.; Shier, W.T. Leaf application of a sprayable bioplastic-based formulation of biocontrol Aspergillus flavus strains for reduction of aflatoxins in corn. Pest Manag. Sci. 2016, 72, 1521-1528. [CrossRef]

140. Kifle, M.H.; Yobo, K.S.; Laing, M.D. Biocontrol of Aspergillus flavus in groundnut using Trichoderma harzianum stain kd. J. Plant Dis. Prot. 2017, 124, 51-56. [CrossRef]

141. Anjaiah, V.; Thakur, R.P.; Koedam, N. Evaluation of bacteria and Trichoderma for biocontrol of pre-harvest seed infection by Aspergillus flavus in groundnut. Biocontrol Sci. Technol. 2006, 16, 431-436. [CrossRef]

142. Garcia, D.; Ramos, A.J.; Sanchis, V.; Marin, S. Effect of Equisetum arvense and Stevia rebaudiana extracts on growth and mycotoxin production by Aspergillus flavus and Fusarium verticillioides in maize seeds as affected by water activity. Int. J. Food Microbiol. 2012, 153, 21-27. [CrossRef] [PubMed]

143. Lagogianni, C.S.; Tsitsigiannis, D.I. Effective biopesticides and biostimulants to reduce aflatoxins in maize fields. Front. Microbiol. 2019, 10, 2645. [CrossRef] [PubMed]

144. Dong, X.; Zhang, Q.; Zhang, Z.; Yue, X.; Zhang, L.; Chen, X.; Zhang, W.; Chen, L.; Li, P. Inhibitory effect of Enterobacter cloacae 3J1EC on Aspergillus flavus 3.4408 growth and aflatoxin production. World Mycotoxin J. 2020, 13, 259-266. [CrossRef]

145. Mohale, S.; Medina, A.; Magan, N. Effect of environmental factors on in vitro and in situ interactions between atoxigenic and toxigenic A-flavus strains and control of aflatoxin contamination of maize. Biocontrol Sci. Technol. 2013, 23, 776-793. [CrossRef]

146. Pitt, J.I. The pros and cons of using biocontrol by competitive exclusion as a means for reducing aflatoxin in maize in Africa. World Mycotoxin J. 2019, 12, 103-112. [CrossRef]

147. Broyde, H.; Dore, T. Effects of cropping systems on food and feed contamination by Fusarium and Aspergillus mycotoxins. Cah. Agric. 2013, 22, 182-194. [CrossRef]

148. Hayes, B.M.E.; Anderson, M.A.; Traven, A.; van der Weerden, N.L.; Bleackley, M.R. Activation of stress signalling pathways enhances tolerance of fungi to chemical fungicides and antifungal proteins. Cell. Mol. Life Sci. 2014, 71, 2651-2666. [CrossRef]

149. Bhatnagar-Mathur, P.; Sunkara, S.; Bhatnagar-Panwar, M.; Waliyar, F.; Sharma, K.K. Biotechnological advances for combating Aspergillus flavus and aflatoxin contamination in crops. Plant Sci. 2015, 234, 119-132. [CrossRef]

150. Krnjaja, V.; Mandić, V.; Stanković, S.; Obradović, A.; Vasić, T.; Lukić, M.; Bijelić, Z. Influence of plant density on toxigenic fungal and mycotoxin contamination of maize grains. Crop Prot. 2019, 116, 126-131. [CrossRef] 
151. Damianidis, D.; Ortiz, B.V.; Bowen, K.L.; Windham, G.L.; Hoogenboom, G.; Hagan, A.; Knappenberger, T.; Abbas, H.K.; Scully, B.T.; Mourtzinis, S. Minimum temperature, rainfall, and agronomic management impacts on corn grain aflatoxin contamination. Agron. J. 2018, 110, 1697-1708. [CrossRef]

152. Mutiga, S.K.; Morales, L.; Angwenyi, S.; Wainaina, J.; Harvey, J.; Das, B.; Nelson, R.J. Association between agronomic traits and aflatoxin accumulation in diverse maize lines grown under two soil nitrogen levels in Eastern Kenya. Field Crops Res. 2017, 205, 124-134. [CrossRef]

153. Hefny, M.; Metwali, E.; Ali, A.; El-Marzouki, H.; Abu Zeid, I. Gene action conditioning resistance to Aspergillus ear rot in maize under water stress conditions. Res. J. Biotechnol. 2018, 13, 34-43.

154. Parimi, V.; Kotamraju, V.K.K.; Sudini, H.K. On-farm demonstrations with a set of good agricultural practices (GAPs) proved cost-effective in reducing pre-harvest aflatoxin contamination in groundnut. Agronomy 2018, 8, 10. [CrossRef]

Publisher's Note: MDPI stays neutral with regard to jurisdictional claims in published maps and institutional affiliations.

(C) 2020 by the authors. Licensee MDPI, Basel, Switzerland. This article is an open access article distributed under the terms and conditions of the Creative Commons Attribution (CC BY) license (http://creativecommons.org/licenses/by/4.0/). 